\title{
Results of the assessment of the council of multidisciplinary pain
}

\section{Multidisipliner ağrı konseyi değerlendirme sonuçları}

\author{
Süleyman DENIZ, Abdulkadir ATIM, Tarik PURTULOĞLU, Ercan KURT
}

\begin{abstract}
Summary
Objectives: The aim of this study was to emphasize the necessity of multidisciplinary pain council by demonstrating the patient profile, treatment approaches, outcomes, and patient satisfaction levels obtained from our council.

Methods: In this study, the age, gender, number of council evaluations, diagnoses and recommended therapies of patients were determined retrospectively. The status of the patients $>1$ year, outcomes of the therapies, and satisfaction levels of the patients were questioned on the phone.

Results: The patients were most commonly diagnosed as chronic low back pain (35\%) and vertebral tumor or metastasis (10\%). $74 \%$ of the patients were evaluated because of vertebral causes. $23 \%$ of the patients had good, $27 \%$ had moderate and $35 \%$ had poor benefit; beneficence was calculated as $85 \%$. Patient satisfaction was found as $24 \%, 23 \%$, and $32 \%$, respectively; satisfaction was calculated as $79 \%$.

Conclusion: Evaluation of complex patients by physicians from different disciplines has better diagnostic and treatment outcomes. In addition, multidisciplinary approach offer and perform different therapy options and this has positive effects on treatment efficiency and patient satisfaction. We are in the opinion that instead of standard treatment protocols, determining individualized multidisciplinary treatment protocols should be useful.
\end{abstract}

Key words: Pain; multidisciplinary; treatment.

\section{Özet}

Amaçઃ Bu çalı̧manın amacı, hastanemizde teşkil edilen multidisipliner ağrı konseyinin hasta profilini, tedavi yaklaşımlarını, tedavi sonuçların ve hasta memnuniyeti düzeylerini ortaya koyarak gerekliliğini vurgulamaktır.

Gereç ve Yöntem: Hastaların yaşı, cinsiyeti, konseyde kaç kez değerlendirildiği, tanısı ve hastalara önerilen tedaviler kayıtlar üzerinden retrospektif olarak tespit edildi. Hastaların $>1$ yll süredeki durumları, tedavilerden fayda görüp görmedikleri ve memnuniyet düzeyleri telefonla sorguland.

Bulgular: Hastalara kronik bel ağrısı (\%35) ve vertebral tümör ya da metastazı (\%10) en sık konulan tanilardı. Hastaların \%74'ü omurga kökenli sebeplerle değerlendirilmişti. Hastaların $\% 23^{3} u ̈$ çok, $\% 27$ 'si orta ve $\% 35^{\prime}$ i az fayda görmüş olup, faydaltlik \%85 olarak hesaplanmıştr. Hasta memnuniyeti $\% 24$ çok, \%23 orta, \%32 az olarak bulunmuş olup, memnuniyet \%79 olarak tespit edilmiştir.

Sonuç: Farklı disiplinlere ait bekimlerin hep birlikte karmaşıı hastaları değerlendirmesi tanı ve tedavi açısından tek başlarına değerlendirmelerinden iyi sonuçlanmaktadır. Ayrıca, multidisipliner yaklaşımla hastalara farklı tedavi seçeneklerinin sunulmast ve uygulanmast tedavi etkinliği ve hasta memnuniyeti üzerine olumlu etki yapmıştrt. Standart tedavi protokolleri yerine kişiye özel tedavi protokollerinin multidisipliner olarak belirlenmesinin faydalı olacağıı düşünmekteyiz.

Anahtar sözcükler: Ağrı; multidisipliner; tedavi.

Department of Anesthesiology, Gulhane Military Medical Faculty, Ankara, Turkey Gulhane Askeri Tıp Fakültesi, Anesteziyoloji ve Reanimasyon Anabilim Dalı, Ankara 


\section{Introduction}

The treatment of chronic pain syndromes including chronic low back pain, facet syndrome, fibromyalgia, and postoperative vertebral surgery is challenging. ${ }^{[1,2]}$ The reason of pain in these disorders is considered to be multifactorial. ${ }^{[1-3]}$ Therefore, the treatment options vary. ${ }^{[1-6]}$ Although several treatment modalities are attempted for these patients, none of them has the same effect on both patients. ${ }^{[1,7,8]}$ Even the effects of the same treatment on similar two patients may differ. Issues like the best treatment regimen and which method has more effective outcomes remain unclear. ${ }^{[1,2]}$ Individualized treatment modalities should be preferred. ${ }^{[1,2,9]}$ Multidisciplinary treatment is considered to be more effective and more useful than any single modality. ${ }^{[1,2,7,8,10]}$ Multidisciplinary treatment approach may be an ideal option for better outcomes, cost-effectiveness, and patient satisfaction.

These disorders are the most common causes of long-term loss of workforce in working population and create a serious problem for health insurance systems. ${ }^{[1,2,11]}$ They also cause high morbidity rates and high costs at older patients. ${ }^{[1]}$ The pain management should be handled seriously for shorter duration to return to work, decreasing the burden on physicians, patient satisfaction, and costeffectiveness.

The aim of this study was to emphasize the necessity of multidisciplinary pain council by demonstrating the patient profile, treatment approaches, outcomes, and patient satisfaction levels obtained from our council.

\section{Methods}

In this study with the approval of the local ethics committee, the age, gender, number of council evaluations, diagnoses, and recommended therapies of 74 patients, who were evaluated by multidisciplinary pain council between January 2010 and December 2010, were determined retrospectively. The status of the patients $>1$ year, outcomes of the therapies, and satisfaction levels of the patients were questioned on the phone.

\section{Working Method of the Council}

Our multidisciplinary pain council is a local unit operating within our hospital. The Pain Unit of Anesthesiology and Reanimation Department host to this unit which serves to patients who applied to our hospital. This unit is established by the deanery and meets between 14:00 and 16:00 every Thursday. The professors (specialist, if absent) from Departments of Anesthesiology and Reanimation (all physicians working at Pain Unit), Physical Medicine and Rehabilitation, Orthopedics, Neurosurgery, Neurology, and Psychiatry are included in this unit. Patients with unresolved chronic pain complaining apply to the council secretary with counseling of the relevant department. Patients are evaluated by Pain Unit physicians and both council members are informed. Both physicians at council evaluate the patients including detailed physical exam and existing diagnosis and laboratory assessments. The conclusion is either reevaluation with further diagnosis and laboratory assessments or therapy planning. The decision of the council is recorded into a notebook and the patient is informed. The patient is free to act in accordance with the decision of the council or not.

Table 1. Demographics and general data

\begin{tabular}{lc}
\hline & $\mathbf{n}$ \\
\hline $\begin{array}{l}\text { Gender } \\
\text { Male }\end{array}$ & $16(22 \%)$ \\
$\quad$ Female & $58(78 \%)$ \\
Average age & $53.9(21-84)$ \\
Number of patients evaluated at council & 74 \\
Number of patients whose treatment was followed & 62 \\
Number of patients who were dead & 5 \\
Number of patients could not be contacted & 7
\end{tabular}


Table 2. Diagnoses*

\begin{tabular}{lc}
\hline Diagnoses & $\mathbf{n}(\%)$ \\
\hline Chronic low back pain & $26(35)$ \\
Spondylolisthesis & $5(7)$ \\
Spinal stenosis & $2(3)$ \\
Neurofibromatosis Type I & $1(1)$ \\
Vertebral tumor or metastasis & $8(10)$ \\
Postoperative hip surgery pain & $3(4)$ \\
Postoperative knee surgery pain & $2(3)$ \\
Morton (Interdigital) neuroma & $1(1)$ \\
Priformis syndrome & $4(5)$ \\
Phantom pain & $2(3)$ \\
Occipital neuralgia & $1(1)$ \\
Postoperative vertebral surgery pain & $5(7)$ \\
Sacroileitis & $2(3)$ \\
Chronic neck pain & $2(3)$ \\
Cauda Equina syndrome & $2(3)$ \\
Facet syndrome & $4(5)$ \\
Complex regional pain syndrome (CRPS) & $2(3)$ \\
Fibromyalgia & $2(3)$ \\
\hline
\end{tabular}

"Diagnoses more than one were considered at 22 patients. The first suspected diagnosis was listed for all patients.

The statistical analysis was performed by using SPSS 18.0 (Chi, Il., USA) program. The results were given as means (minimum-maximum) and percentages.

\section{Results}

58 of the patients were women and 16 were men, and the average age was $53.9(21-84)$ (Table 1$)$.

A total of 98 evaluations were performed by the council; three in 3 patients, two in 18 patients, and one in 53 patients.

The patients were most commonly diagnosed as chronic low back pain (35\%) and vertebral tumor or metastasis (10\%) (Table 2). $74 \%$ of the patients were evaluated because of vertebral causes.

The treatment decisions of the council are shown at Table 3.51 patients were treated with invasive pain therapy by Pain Unit of Anesthesiology and Reanimation Department, 9 were treated with surgical treatments by Orthopedics and Neurosurgery Departments, 10 were trated with medical therapy by
Neurology Department, 19 were treated by Physical Medicine and Rehabilitation Department, and 2 were treated with psychotherapy by Psychiatry Department. 52 patients had multiple therapies at the same time.

Treatment outcomes and patient satisfaction levels are shown at Table $4.23 \%$ of the patients had good, $27 \%$ had moderate and $35 \%$ had poor benefit; beneficence was calculated as $85 \%$. Patient satisfaction was found as $24 \%, 23 \%$, and $32 \%$, respectively; satisfaction was calculated as $79 \%$.

\section{Discussion}

Seventy-four patients with chronic pain syndrome were detected from records between January 2010 and December 2010, and we were able to access to 62 of them on the phone. $85 \%$ of these patients benefited from the therapies. The level of patient satisfaction was determined as $79 \%$. As the outcomes were measured $>1$ year, the treatment modalities are considered to have high benefits and provide satisfaction. 
Table 3. Council decisions ${ }^{*}$

\begin{tabular}{|c|c|}
\hline Decision & $\mathbf{n}$ \\
\hline Reevaluation & 24 \\
\hline Transforaminal anterior epidural steroid injection & 8 \\
\hline Treatment with Pulse Radiofrequency (including DRG) & 6 \\
\hline Medical therapy & 20 \\
\hline Spinal surgery & 8 \\
\hline Facet Nerve denervation with Radiofrequency & 7 \\
\hline Transcutaneous electrical nerve stimulation (TENS) & 2 \\
\hline İnterdigital blockage & 1 \\
\hline Priformis muscle blockage & 4 \\
\hline Caudal blockage & 2 \\
\hline Radiofrequency ablation therapy & 6 \\
\hline Cordotomy & 1 \\
\hline Occipital blockage & 1 \\
\hline Prosthesis revision operation & 1 \\
\hline Sacroiliac joint injection & 2 \\
\hline Physiotherapy protocols & 7 \\
\hline Spinal cord stimulator & 3 \\
\hline Psychotherapy & 2 \\
\hline Lumbar sympathetic blockage & 2 \\
\hline Thoracic sympathetic blockage & 2 \\
\hline Continuous epidural catheter placement & 1 \\
\hline Continuous spinal catheter placement & 1 \\
\hline Dry needle therapy & 2 \\
\hline Stellar ganglion blockage & 2 \\
\hline
\end{tabular}

*Decisions more than one were made for 52 patients.

In a study of 395 patients with chronic low back pain, Moradi et al. ${ }^{[1]}$ applied multidisciplinary therapy approaches including physical exercises, ergonomic education, psychotherapy, patient education, behavioral therapy, and workplace based interventions individually or on groups. Tests including visual analog scale (VAS), functional capacity (Funktions fragebogen Hannover- Ruecken [FFbH-R]), ${ }^{[12]}$ pain disability (Pain Disability Index German [PDI-G]), ${ }^{[13,14]}$ quality of life (36-item Short Form Health Survey [SF- 36] $)^{[15]}$ and Center for Epidemiological Studies- Depression Scale (CES-D) ${ }^{[16]}$ were used to evaluate treatment efficiency. Multidisciplinary therapy approach was determined to be the best method for improving patient function and physical condition, and resolving psychosocial disorders. ${ }^{[1]}$ Invasive interventional treatment options were not performed and evaluated in this study. In addition to stated therapy options, invasive methods were also included in our study. We are in the opinion that invasive interventional treatment options may improve patient satisfaction and beneficence at chosen patients with chronic pain.

The majority of the patients applied to the council were above mid-age $(>40)$. The benefit rate of therapies is low in this patient population. ${ }^{[1,17]}$ Although benefit rate is low for advanced age patient group, multidisciplinary therapy procedures are beneficial for all age groups. ${ }^{[5,17-19]}$

The chronic pain problem is usually not limited to a single region at advanced-age patients. The patients commonly have other painful areas and complaints. Multidisciplinary therapy techniques also decrease the pain in other regions in addition to the main 
Table 4. Treatment outcomes and patient satisfactions ${ }^{*}$

\begin{tabular}{lc}
\hline & $\mathbf{n}(\%)$ \\
\hline Benefit of treatment & \\
Good & $14(23)$ \\
Moderate & $17(27)$ \\
Poor & $22(35)$ \\
None & $9(15)$ \\
Patient satisfaction & \\
Good & $15(24)$ \\
Moderate & $14(23)$ \\
Poor & $20(32)$ \\
None & $13(21)$ \\
\hline
\end{tabular}

*Results at follow-up $>1$ year treatment.

area of pain. ${ }^{[1,20]}$ Our high satisfaction rate and experience support this information, too.

Studies on outcomes of multidisciplinary therapy techniques detected increase at disease-free survival, significant decrease at treatment cost and faster return to work. ${ }^{[21-23]}$ Although these evaluation criteria were not investigated in our study, our clinical experience supports these findings.

Another important limitation of our study was being unable to compare the data provided by special tests (functional capacity, pain disability, quality of life and Center for Epidemiological Studies- Depression Scale). Performing these tests on the phone is impossible. Our patients were mostly older and had poor cooperation. Thus, satisfaction and benefit were evaluated by asking basic and easy-to-answer questions.

Invasive treatment options were found to have little effect for chronic low back pain at short and longterm. ${ }^{[24]}$ Our invasive treatment options varied more due to technological developments. We are in the opinion that technology based treatment techniques including spinal cord stimulator, radiofrequency ablation, cordotomy, and sympathetic blockage improve efficiency and patient satisfaction.

Prospective, randomized, controlled, double blind studies on multidisciplinary therapy should be performed and treatment options should be investigated in the light of technological developments.

\section{Conclusions}

Evaluation of complex patients by physicians from different disciplines has better diagnostic and treatment outcomes. In addition, multidisciplinary approach offer and perform different therapy options and this has positive effects on treatment efficiency and patient satisfaction. We are in the opinion that instead of standard treatment protocols, determining individualized multidisciplinary treatment protocols should be useful.

\section{Conflict-of-interest issues regarding the authorship or article: None declared.}

\section{Peer-review: Externally peer-reviewed.}

\section{References}

1. Moradi B, Hagmann S, Zahlten-Hinguranage A, Caldeira F, Putz C, Rosshirt N, et al. Efficacy of multidisciplinary treatment for patients with chronic low back pain: a prospective clinical study in 395 patients. J Clin Rheumatol 2012;18 (2):76-82.

2. Sarzi-Puttini P, Atzeni F, Salaffi F, Cazzola M, Benucci M, Mease PJ. Multidisciplinary approach to fibromyalgia: what is the teaching? Best Pract Res Clin Rheumatol 2011;25(2):311-9.

3. Van der Hulst M, Vollenbroek-Hutten MM, ljzerman MJ. A systematic review of sociodemographic, physical, and psychological predictors of multidisciplinary rehabilitation-or, back school treatment outcome in patients with chronic low back pain. Spine (Phila Pa 1976) 2005;30(7):813-25.

4. Karjalainen $K$, Malmivaara $A$, van Tulder $M$, Roine $R$, Jauhiainen $M$, Hurri $H$, et al. Multidisciplinary biopsychosocial rehabilitation for subacute low back pain in working-age adults: a systematic review within the framework of the Cochrane Collaboration Back Review Group. Spine (Phila Pa 1976) 2001;26(3):262-9.

5. Guzmán J, Esmail R, Karjalainen K, Malmivaara A, Irvin E, 
Bombardier C. WITHDRAWN: Multidisciplinary bio-psychosocial rehabilitation for chronic low-back pain. Cochrane Database Syst Rev 2007;18:CD000963.

6. Cairns D, Mooney V, Crane P. Spinal pain rehabilitation: inpatient and outpatient treatment results and development of predictors for outcome. Spine (Phila Pa 1976) 1984;9(1):915.

7. Guzmán J, Esmail R, Karjalainen K, Malmivaara A, Irvin E, Bombardier C. Multidisciplinary rehabilitation for chronic low back pain: systematic review. BMJ 2001;322(7301):15116.

8. Jensen IB, Bergström G, Ljungquist T, Bodin L. A 3-year follow-up of a multidisciplinary rehabilitation programme for back and neck pain. Pain 2005;115(3):273-83.

9. Gatchel RJ, Mayer TG. Evidence-informed management of chronic low back pain with functional restoration. Spine J 2008;8(1):65-9.

10. Patrick LE, Altmaier EM, Found EM. Long-term outcomes in multidisciplinary treatment of chronic low back pain: results of a 13-year follow-up. Spine (Phila Pa 1976) 2004;29(8):8505.

11. Badley EM, Rasooly I, Webster GK. Relative importance of musculoskeletal disorders as a cause of chronic health problems, disability, and health care utilization: findings from the 1990 Ontario Health Survey. J Rheumatol 1994;21(3):505-14.

12. Lautenschläger J, Mau W, Kohlmann T, Raspe HH, Struve F, Brückle W, Zeidler H. Comparative evaluation of a German version of the Health Assessment Questionnaire and the Hannover Functional Capacity Questionnaire. Z Rheumatol 1997;56(3):144-55.

13. Chibnall JT, Tait RC. The Pain Disability Index: factor structure and normative data. Arch Phys Med Rehabil 1994;75(10):1082-6.

14. Tait RC, Chibnall JT, Krause S. The Pain Disability Index: psychometric properties. Pain 1990;40(2):171-82.

15. Ware JE Jr, Sherbourne CD. The MOS 36-item short-form health survey (SF-36). I. Conceptual framework and item selection. Med Care 1992;30(6):473-83.

16. Radloff LS, Rae DS. Susceptibility and precipitating factors in depression: sex differences and similarities. J Abnorm Psychol 1979;88(2):174-81.

17. Buchner M, Neubauer E, Zahlten-Hinguranage A, Schiltenwolf $M$. Age as a predicting factor in the therapy outcome of multidisciplinary treatment of patients with chronic low back pain--a prospective longitudinal clinical study in 405 patients. Clin Rheumatol 2007;26(3):385-92.

18. Scascighini L, Toma V, Dober-Spielmann S, Sprott H. Multidisciplinary treatment for chronic pain: a systematic review of interventions and outcomes. Rheumatology (Oxford) 2008;47(5):670-8.

19. Smeets RJ, Vlaeyen JW, Hidding A, Kester AD, van der Heijden GJ, Knottnerus JA. Chronic low back pain: physical training, graded activity with problem solving training, or both? The one-year post-treatment results of a randomized controlled trial. Pain 2008;134(3):263-76.

20. Moradi B, Zahlten-Hinguranage A, Barié A, Caldeira F, Schnatzer $P$, Schiltenwolf $M$, et al. The impact of pain spread on the outcome of multidisciplinary therapy in patients with chronic musculoskeletal pain - a prospective clinical study in 389 patients. Eur J Pain 2010;14(8):799-805.

21. Jensen IB, Busch H, Bodin L, Hagberg J, Nygren A, Bergström $G$. Cost effectiveness of two rehabilitation programmes for neck and back pain patients: a seven year follow-up. Pain 2009;142(3):202-8

22. Flor $\mathrm{H}$, Fydrich T, Turk DC. Efficacy of multidisciplinary pain treatment centers: a meta-analytic review. Pain 1992;49(2):221-30.

23. Demoulin C, Grosdent S, Capron L, Tomasella M, Somville PR, Crielaard JM, et al. Effectiveness of a semi-intensive multidisciplinary outpatient rehabilitation program in chronic low back pain. Joint Bone Spine 2010;77(1):58-63.

24. Keller A, Hayden J, Bombardier C, van Tulder M. Effect sizes of non-surgical treatments of non-specific low-back pain. Eur Spine J 2007;16(11):1776-88. 